\title{
The phenomenon of human conscience
}

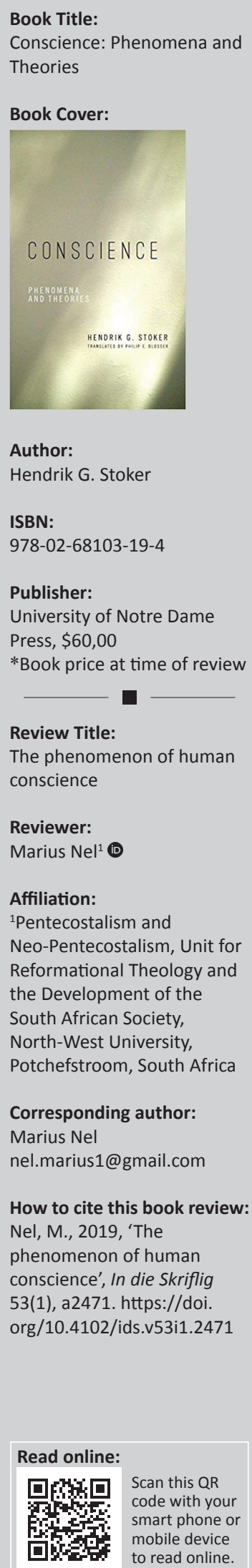

The late South African philosopher, Hendrik Stoker (1899-1993), spent his professional life in Potchefstroom where he lectured in philosophy (from 1925 to 1970) and contributed to the pre1994 character of the university in terms of Christian higher education and a strong philosophical tradition underlying all scientific endeavours. As an eminent philosopher in the Afrikaner Reformed tradition, he was affiliated to the neo-Kuyperian tradition of reformational philosophy pioneered by Herman Dooyeweerd and Dirk H. Th. Vollenhoven, and the neo-Calvinist movement stemming from Abraham Kuyper and Herman Bavinck. He developed his 'Theistic philosophy' or 'Philosophy of the creation-idea' in contrast to Dooyeweerd and Vollenhoven's 'Philosophy of the cosmomonic idea', because the creation was a more encompassing principle for Stoker than the laws of creation.

For his doctorate, he studied with Max Scheler in Cologne and adapted Scheler's phenomenological method to his own Reformed outlook. Although his book on the conscience of humankind is a dissertation, it does not read like one, because the author presents his argumentation in such a logical and cogent form that any intelligent reader can follow the main lines. In his study, he utilises the philosophical method of phenomenology as initiated by Edmund Husserl and further developed by Scheler.

In his view of conscience, evil is a necessary presupposition. One cannot regard conscience without a personal awareness of moral responsibility for evil. His view of evil is determined by his dependence on Augustine and Calvin's radical view of original sin with reference to the state of $\sin$ in which humanity has existed since the fall of Genesis 3 which stemmed from Adam and Eve's rebellion and disobedience to God in the Garden of Eden that tainted all their seed.

In the book, Stoker provides a detailed historical survey of the concept of conscience from ancient times to the time of writing in the 1920s. He analyses the concept of conscience in various academic theories, discusses entertainingly various terms and colloquial proverbs for conscience and their etymologies. He describes the various types of theories of conscience that he divides into intellectualist, intuitivist, voluntarist and emotionalist based on the different views of conscience as residing in moral inferences and moral intuitions, moral volitions and inclinations or moral feelings. Three questions are asked: What is conscience, with a distinction between moral knowledge, moral willing and moral feeling?; How does conscience arise?; and Is it reliable? He distinguishes between conscience in its proper sense as a real internal disclosure of personal evil that is infallible and, in its secondary sense, as a deposit of insight into the good that is fallible. Conscience implies a transcendent Judge who summons us to account by implying a relatedness to God. It is ultimately an emotional and momentous experience, but it involves moral knowledge, will and aspirations.

As a phenomenological study, the author takes care to analyse the diverse moral, psychological and spiritual phenomena associated with the experience of bad conscience which he views as of decisive significance for understanding conscience. He contrasts it to bio-genetic claims of evolutionists and other reductionist theories. Human beings exhibit subject-object awareness and are not completely immersed in their milieu such as animals which distinguish human beings from animals.

The book was received with acclaim by Max Scheler, Martin Heidegger and Herbert Spielberg as a major contribution to the phenomenological tradition. Due to a waning interest in phenomenology and Christian philosophy as well as disagreements within Calvinism with Stoker, the German dissertation, published in 1925, was never translated into English until Philip Blosser did his excellent translation in 2018 which is enriched with many footnotes of his own.

The book will be valuable for philosophers and psychologists in whose field the study was done, but also for theologians, epistemologists and people interested in moral issues and religion in general.

Copyright: @ 2019. The Authors. Licensee: AOSIS. This work is licensed under the Creative Commons Attribution License. 
That the book is a German doctoral dissertation, ensures the highest standards of scholarship. Stoker's discussion and analysis of different theories of conscience, including Immanuel Kant, Friedrich Nietzsche and Sigmund Freud, provides a good introduction to the subject. His study on the genesis of conscience and the necessity to investigate the phenomenon of bad conscience if one wants to comprehend the phenomenon, especially provides interesting and stimulating insights. Although the methodology, which is used in the book to analyse the phenomenon of conscience, is no longer the trend, most of its conclusions are still convincing and valid. One should, however, keep in mind that Stoker, the philosopher, is practising his trade and one will not find much of a theological discussion. What he writes is appropriate to all religions, although it can also be applied to the Christian religion. However, one does not find any discussion of biblical data concerning the phenomenon. 